Marcin Krawczak $^{1}$

Instytut Ekonomiki Rolnictwa i Gospodarki Żywnościowej - Państwowy Instytut

Badawczy w Warszawie

\title{
Wartość dodana na wybranych gałęziach polskiego rynku żywnościowego
}

\section{Value Added on Selected Branches of the Polish Food Market}

\begin{abstract}
Synopsis. Pojęcie wartości dodanej nie jest jednolite. W literaturze można znaleźć kilka odmiennych od siebie definicji. Część z nich zostały przedstawione w niniejszym artykule artykułu wraz z różnymi metodami jej obliczania. Analizie poddano dynamikę wartości dodanej, gdzie stwierdzono, że z badanych gałęzi przemysłu spożywczego najlepiej rozwija się „Produkcja wyrobów z mięsa, włączając wyroby z mięsa drobiowego". Następnie określono udział wartości dodanej w wielkości sprzedaży, udział poszczególnych składników w samej wartości dodanej oraz obliczono i zinterpretowano współczynniki zmienności tych składników. Ponadto zbadano wydajność w wytwarzaniu wartości dodanej na jednego pracownika, gdzie nie tylko najlepszą wydajnością, ale także najszybciej poprawiającą się wydajnością w analizowanym okresie stwierdzono w gałęzi przemysłu „Wytwarzanie produktów przemiału zbóż”.
\end{abstract}

Słowa kluczowe: wartość dodana, przemysł spożywczy, łańcuch marketingowy żywności, rachunek zysków i strat

\begin{abstract}
The notion of added value is not uniform. Several definitions can be found in the literature. Some of them are presented in this article, along with various methods of its calculation. The analysis of the added-value dynamics was analyzed, where it was found that the most studied branches of the food industry were under the category of "Production of meat products, including products from poultry meat". Next, the share of value added in the sales volume, the share of individual components in the added value itself was determined and the coefficients of variation of these components were calculated and interpreted. In addition, the efficiency in the production of added value per employee was examined, where not only the best performance, but also the fastest improving efficiency in the analyzed period was found in the industry category "Manufacture of grain mill products".
\end{abstract}

Key words: value added, food industry, food marketing chain, income statement

JEL Classification: L11, O16

\section{Wprowadzenie}

Łańcuch marketingowy żywności łączy podmioty należące do trzech sektorów gospodarki: rolnictwo, produkcję spożywczą oraz sprzedaż (dystrybucję). Te podmioty w literaturze nazywane są ogniwami. W zależności od specyfiki produktów finalnych, odpowiadające im łańcuchy mogą mieć różną ilość ogniw (Hamulczuk i in., 2015). Zazwyczaj pisze się o trzech ogniwach, gdzie każdy odpowiada za jeden z wymienionych sektorów gospodarki (Jarzębiowski i Klepacki, 2013). Między kolejnymi ogniwami

${ }^{1}$ mgr, IERiGŻ-PIB, ul. Świętokrzyska 20, 00-002 Warszawa, e-mail: Marcin.Krawczak@ierigz.waw.pl; https://orcid.org/0000-0002-9480-9585. 
łańcucha wytwarzana jest tzw. wartość dodana. Wartością dodaną jest wytworzenie w procesie produkcyjnym wzrost wartości towaru (Słownik PWN). Z tego powodu celem przedsiębiorstw jest wytwarzanie wartości dodanej, bowiem to z niej opłacane są wszelkie koszty związane z produkcją, a także inwestycje w rozwój przedsiębiorstwa.

Analiza została przeprowadzona na danych GUS (niepublikowanych), które zawierają sprawozdania finansowe podmiotów zatrudniających ponad 9 pracujących. Dane obejmują okres 2009-2016. Analizie poddano 3 klasy: 10.13, 10.51 i 10.61. Pochodzą one z działu Produkcja artykułów spożywczych. Według PKD (Polskiej Klasyfikacji Działalności) klasa 1013 oznacza „Produkcja wyrobów z mięsa, włączając wyroby z mięsa drobiowego”, klasa 10.51 „Przetwórstwo mleka i wyrób serów”, a klasa 10.61 „Wytwarzanie produktów przemiału zbóż". Wybrano te klasy ze względu na ich różnorodność czy to w wytwarzaniu wartości dodanej, kierunku i sile trendu, udziału składników w wartości dodanej czy to w wydajności jej wytwarzania.

Celem artykułu jest ocena efektywności wybranych klas w wytwarzaniu wartości dodanej, analiza trendu w jej wytwarzaniu oraz rozpoznanie głównych składników wartości dodanej.

\section{Przegląd literatury i metodologii}

Na przestrzeni lat zaproponowano wiele definicji wartości dodanej, a co za tym idzie, różne metody jej obliczania. Przykładowymi definicjami są:

- Wartość dodana to wzrost wartości rynkowej związany ze zmianą formy, lokalizacji lub dostępności produktu lub usług z wyłączeniem kosztów związanych z materiałami i usługami (David, 1985).

- Wartość dodana odzwierciedla całkowity majątek firmy, który mógłby zostać przekazany wszystkim dostawcom kapitału, pracownikom i rządowi (Evraret i Belkaoui, 1988).

- Wartość dodana to bogactwo, które firma była w stanie przeznaczyć na własne działania i wysiłki swoich pracowników w danym okresie (Sizer, 1979).

- Wytworzona w danym okresie przez przedsiębiorstwa nowa wartość, stanowiąca różnicę między utargiem każdej jednostki gospodarczej (...) a wartością zakupionych (...) materiałów i usług obcych (Główczyk, 2000).

Zatem ogólnie rzecz ujmując, wartość dodana to przyrost wartości dóbr w danym okresie.

Jedną z pierwszych zaproponowanych metod obliczania wartości dodanej jest równanie zaproponowane przez Morleya (Morley, 1979):

$$
Z=S-M-A m-W-I-D D-T,
$$

gdzie:

$Z$ - zysk zatrzymany,

$S$ - sprzedaż,

$M$ - zakupione materiały i usługi,

$A m$ - amortyzacja,

$W$ - wynagrodzenia, 
$I$ - odsetki,

$D D$ - dywidendy,

$T$ - podatki.

Aby otrzymać wartość dodaną brutto należy przekształcić wzór 1 do postaci:

$$
S-M=A m+W+I+D D+T+Z,
$$

A z kolei wartość dodana netto dana jest wzorem:

$$
S-M-A m=W+I+D D+T+Z,
$$

Lewa strona równan 2 i 3 jest zgodna z definicją Główczyka. Z kolei prawa strona równań określa kierunek dystrybucji wartości dodanej.

Podobną metodę zaproponował Urban (Urban, 2002), który określił wartość dodaną brutto jako sumę: wynagrodzeń, amortyzacji, podatków obciążających koszty (bez VAT i akcyzy), kosztów finansowych i wyniku finansowego brutto. Urban analizował między innymi poziom i strukturę wartości dodanej w przemyśle spożywczym w latach 1994, 1999-2001 (pierwsze półrocze) w kilku podstawowych działach przemysłu spożywczego oraz osobno w całym przemyśle spożywczym. Doszedł on do wniosku, że wynagrodzenia stanowią ponad $50 \%$ wartości dodanej brutto. Ponadto przemysł spożywczy zwiększył swój udział w wytwarzaniu wartości dodanej brutto w stosunku do całego przemysłu w badanych latach.

Trzecia metoda została opracowana przez FADN (Sielska i in., 2015), która wartość dodaną brutto określa jako różnicę między całkowitą produkcją osiągniętą w gospodarstwie a zużyciem pośrednim. Tą różnicę należy skorygować saldo dopłat i podatków dotyczących działalności operacyjnej. $Z$ kolei produkcja całkowita jest sumą produkcji:

- roślinnej, do której zalicza się zużycie wewnętrzne, sprzedaż produktów roślinnych, przekazanie poza gospodarstwo rolne (nieodpłatne) i różnicę stanu zapasów,

- zwierzęcej, do której zalicza się zużycie wewnętrzne produktów pochodzenia zwierzęcego i zwierząt, sprzedaż, przekazanie poza gospodarstwo rolne (nieodpłatne)

- pozostałej, która obejmuje pozostałe przychody gospodarstwa.

Obszerniejszy opis definicji można znaleźć w pracy Lorenc (Lorenc, 2016).

Zdecydowano się na wykorzystanie metody zaproponowanej przez Urbana.

\section{Weryfikacja empiryczna}

Analizą zostały objęte trzy klasy PKD, a mianowicie produkcję wyrobów z mięsa, włączając wyroby z mięsa drobiowego (10.13), przetwórstwo mleka i wyrób serów (10.51) i wytwarzanie produktów przemiału zbóż (10.61). Dalej w celu uproszczenia nazywane po prostu numerem klasy.

W analizowanym okresie (2009-2016) można zauważyć, że produkcja wyrobów z mięsa, włączając wyroby z mięsa drobiowego oraz przetwórstwo mleka i wyrób serów charakteryzują się około 3-4 krotnie większą wartością dodaną brutto niż wytwarzanie 
produktów przemiału zbóż. Do 2013 roku przetwórstwo mleka i wyrób serów dominowała nad pozostałymi. W kolejnych latach produkcja wyrobów z mięsa, włączając wyroby $\mathrm{z}$ mięsa drobiowego miała największy wkład w wytwarzanie wartości dodanej.

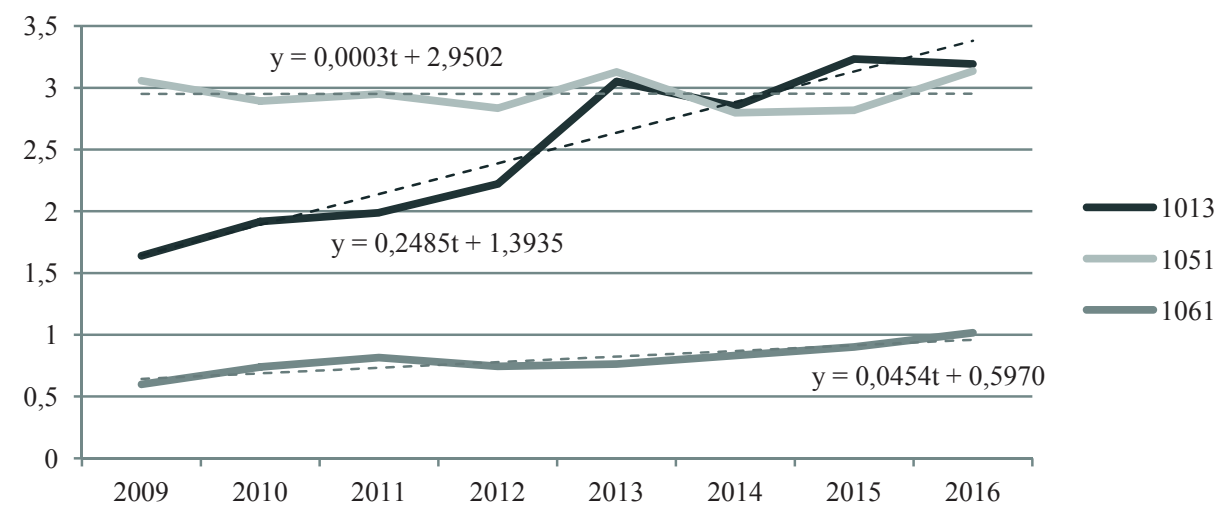

Rys. 1. Poziom wartości dodanej brutto w wybranych klasach

Fig. 1. The level of gross value added in selected classes

Źródło: opracowanie własne na podstawie danych GUS.

Wartość dodana brutto w roku 2016 dla wytwarzania produktów przemiału zbóż była większa niż w początkowym okresie o $69,94 \%$. Wynik ten jest znacznie większy w porównaniu do przetwórstwa mleka i wyrób serów, w której rozwój wyniósł jedynie 2,62\% co oznacza niemalże stagnację. Szczególny przypadek wystąił dla produkcji wyrobów z mięsa, włączając wyroby z mięsa drobiowego gdzie współczynnik ten wynosił 94,73\% co oznacza prawie dwukrotny wzrost wytworzenia nowej wartości dóbr. Analiza funkcji trendu potwierdza wysnute wnioski. Dla przetwórstwa mleka i wyrobu serów współczynnik przy trendzie jest niewielki i nieistotny statystycznie. Z kolei dla produkcji wyrobów z mięsa, włączając wyroby z mięsa drobiowego współczynnik przy trendzie był dość wyskoki $(0,2485)$.

Według wzoru 2 wartość dodana brutto to wartość sprzedaży pomniejszona o wartość zakupu materiałów i usług. Inaczej ujmując suma wartości dodanej brutto i wartości zakupionych materiałów i usług jest wartością sprzedaży. Strukturę tych dwóch składowych sprzedaży zaprezentowano na rysunku 2. 
1013

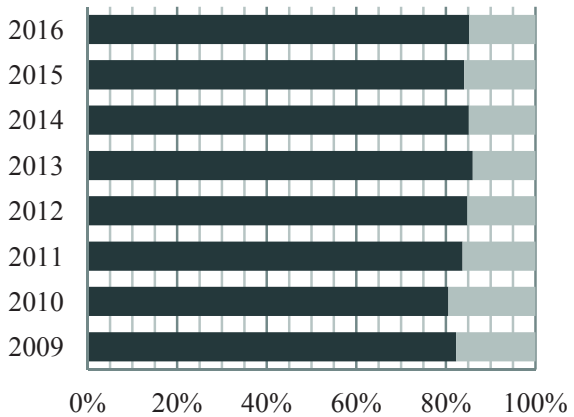

1051

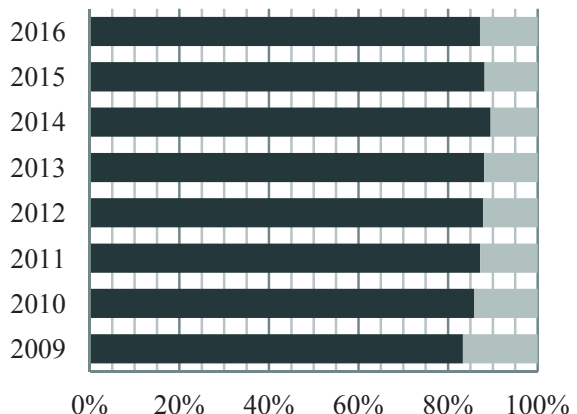

1061

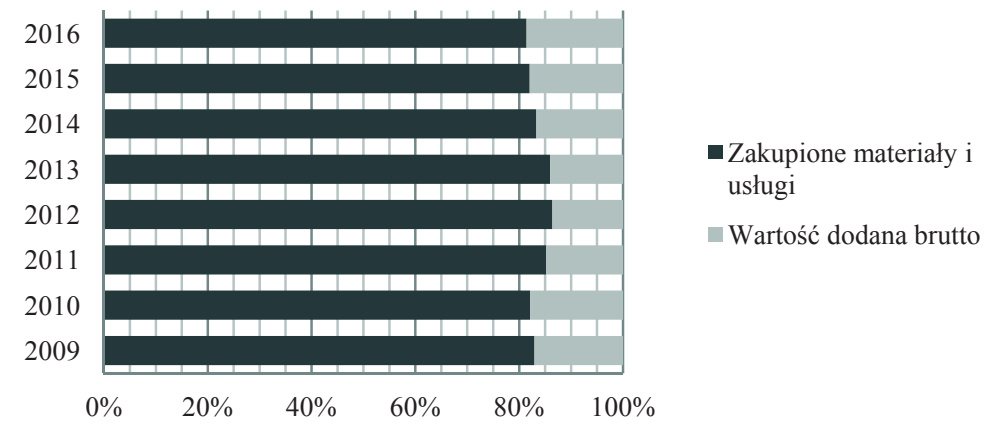

Rys. 2. Struktura wartości sprzedaży

Fig. 2. Sales value structure

Źródło: opracowanie własne na podstawie danych GUS.

Im większą część wielkości sprzedaży jest wartość dodana brutto tym lepsza sytuacja gospodarcza, ponieważ wtedy po opłaceniu pozostałych poniesionych w procesie produkcji wydatków (np. wynagrodzenia) większą ilość pieniędzy można zainwestować w rozwój działalności. Jak można zauważyć z rysunku 2, przetwórstwo mleka i wyrób serów miało stosunkowo najmniejszą wartość dodaną brutto i jednocześnie poziom wartości dodanej brutto w badanym okresie oscylował wokół wartości 3 mld zł. Warto również zauważyć, że gdy w produkcji wyrobów z mięsa, włączając wyroby z mięsa drobiowego udział wartości dodanej brutto w wielkości sprzedaży zmalał z około $18-19 \%$ do $14-15 \%$ to z pewnym opóźnieniem dynamika wartości dodanej brutto znacznie zmalała.

Istotną kwestią jest również struktura wartości dodanej brutto. Jej graficzną prezentację zawarto w rysunku 3. 
1013

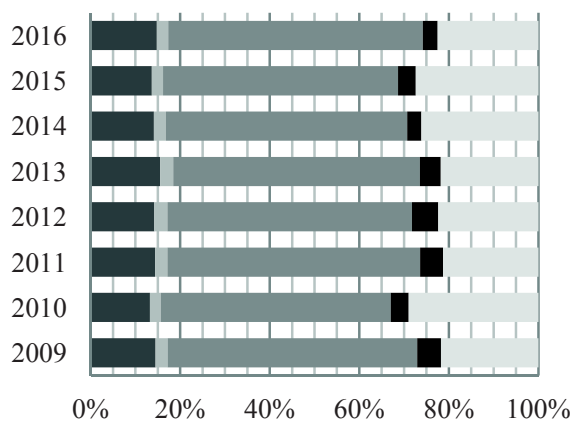

1051

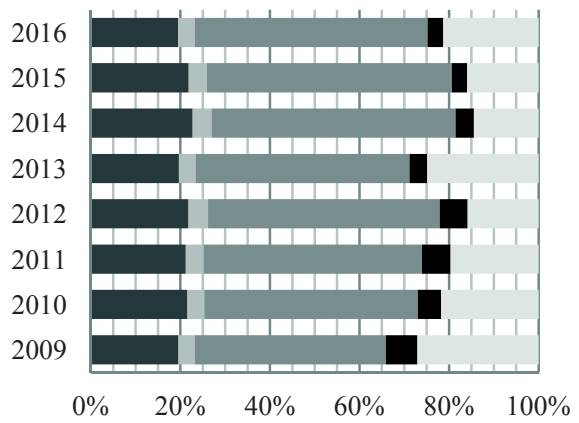

1061

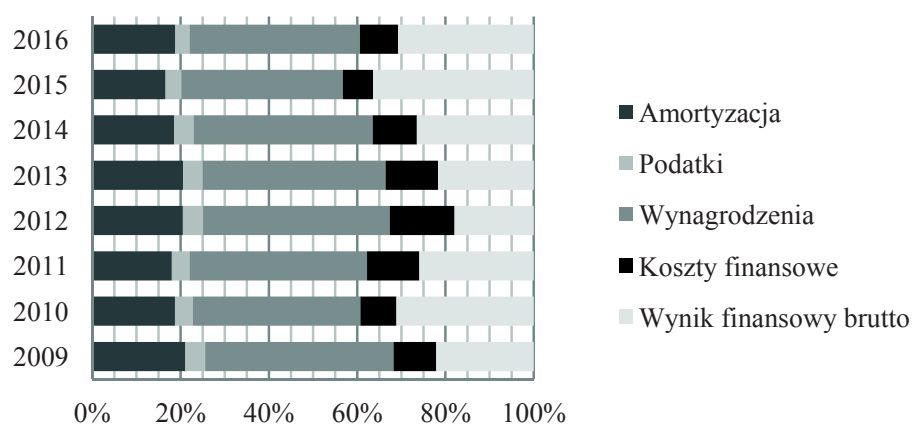

Rys. 3. Struktura wartości dodanej brutto

Fig. 3. Gross value added structure

Źródło: opracowanie własne na podstawie danych GUS.

Jak można zaobserwować, głównym składnikiem wartości dodanej brutto jest we wszystkich trzech klasach było wynagrodzenie, gdzie dla produkcję wyrobów z mięsa, włączając wyroby z mięsa drobiowego zajmuje około 55\% udziału w wartości dodanej brutto w całym badanym okresie, dla wytwarzania produktów przemiału zbóż około $40 \%$, a dla przetwórstwa mleka i wyrobu serów początkowo wynagrodzenie zajmowało niecałe $43 \%$, by pod koniec badanego okresu zajmowało ponad $50 \%$ udziału. Drugim co do wielkości składnikiem jest wynik finansowy brutto. Ten składnik charakteryzuje się różnym udziałem w wartości dodanej brutto nie tylko w poszczególnych klasach, ale również w poszczególnych latach. Trzecim składnikiem jest amortyzacja, która jednak w obrębie danej klasy pod względem udziału była dość stabilna. Podatki i koszty finansowe miały niewielki udział w wartości dodanej brutto. Najważniejszym składnikiem jest wynik finansowy brutto, ponieważ to z tego składnika pochodzą inwestycje na dalszy rozwój i modernizację przedsiębiorstwa. 
Tabela 1. Współczynnik zmienności wśród analizowanych klas

Table 1. Coefficient of variation among the analyzed classes

\begin{tabular}{c|ccccccc}
\hline & Amortyzacja & $\begin{array}{c}\text { Zakupione } \\
\text { materiały i } \\
\text { usługi }\end{array}$ & Podatki & Wynagrodzenia & $\begin{array}{c}\text { Koszty } \\
\text { finansowe }\end{array}$ & $\begin{array}{c}\text { Wynik } \\
\text { finansowy } \\
\text { brutto }\end{array}$ & $\begin{array}{c}\text { Wartość } \\
\text { dodana } \\
\text { brutto }\end{array}$ \\
\hline 1013 & 0,2546 & 0,3182 & 0,2445 & 0,2408 & 0,2044 & 0,2759 & 0,2382 \\
1051 & 0,0170 & 0,1289 & 0,0359 & 0,0638 & 0,2721 & 0,2456 & 0,0440 \\
1061 & 0,1148 & 0,1503 & 0,0824 & 0,1185 & 0,2202 & 0,3202 & 0,1446 \\
\hline
\end{tabular}

Źródło: opracowanie własne na podstawie danych GUS.

Analizując współczynniki zmienności zaprezentowanych w tabeli 1 stwierdzono, że wynik finansowy brutto charakteryzuje się dużą zmiennością we wszystkich trzech analizowanych klasach. Zazwyczaj duża zmienność jest negatywną cechą, ale należy zaznaczyć, że wynik finansowy brutto w badanym okresie utrzymywał tendencję rosnącą dla produkcji wyrobów z mięsa, włączając wyroby z mięsa drobiowego oraz wytwarzania produktów przemiału zbóż. Jedynie w przetwórstwie mleka i wyrób serów wynik finansowy brutto nie utrzymywał żadnej tendencji, czy to rosnącej czy malejącej, a raczej miał charakter „skaczący” tzn. wynik finansowy brutto w jednym roku mógł osiagnąc (znacznie) wyższą wartość niż rok wcześniej, a już w kolejnym (znacznie) niższą wartość. Taki „skaczący” charakter występował również w kosztach finansowych, ale tym razem już dla wszystkich trzech klas, co jest raczej typową sytuacją. Dokładne zestawienie poszczególnych składników wartości dodanej brutto zawiera rysunek 5. Użytą jednostką na osi Y jest mld zł.

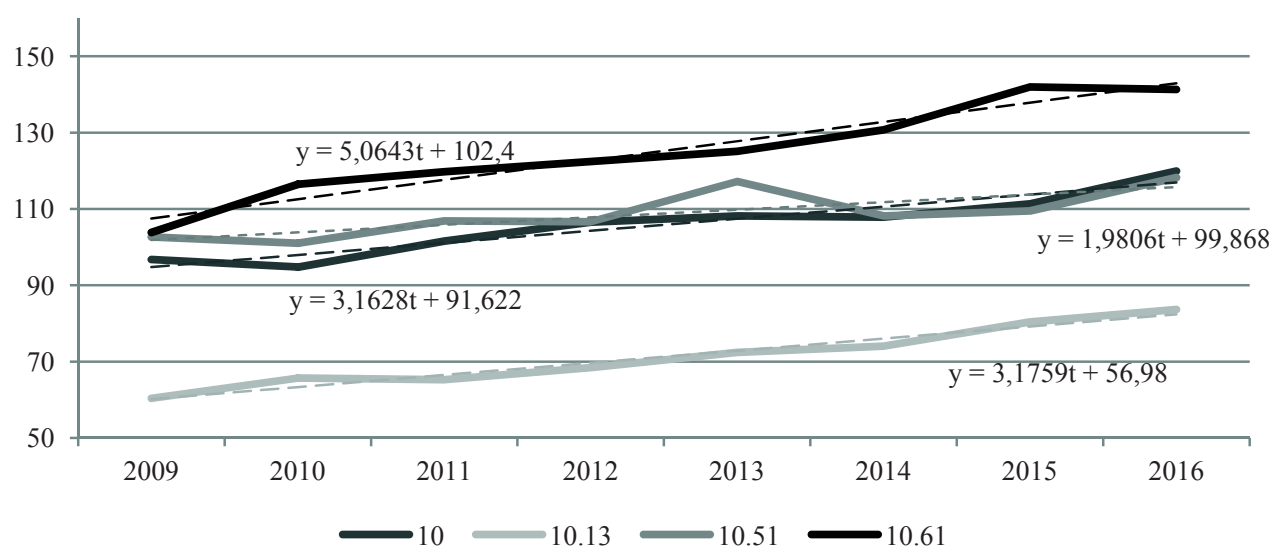

Rys. 4. Wartość dodana wytwarzane przez jednego pracownika

Fig. 4. Value added generated by one employee

Źródło: opracowanie własne na podstawie danych GUS. 
1013

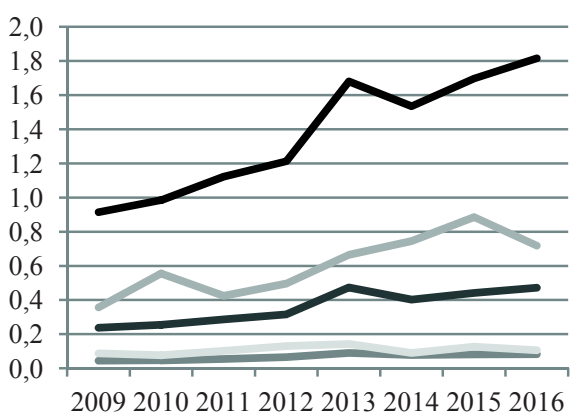

1061

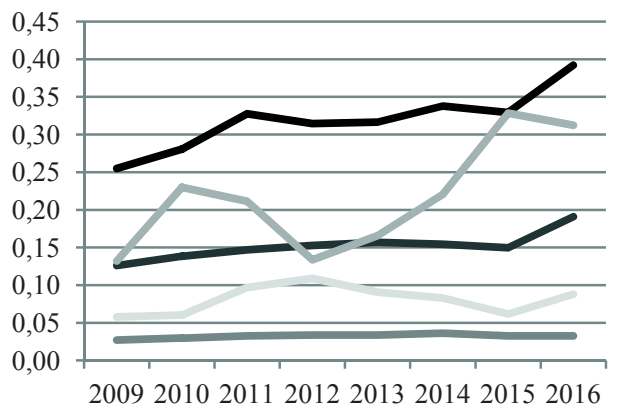

1051
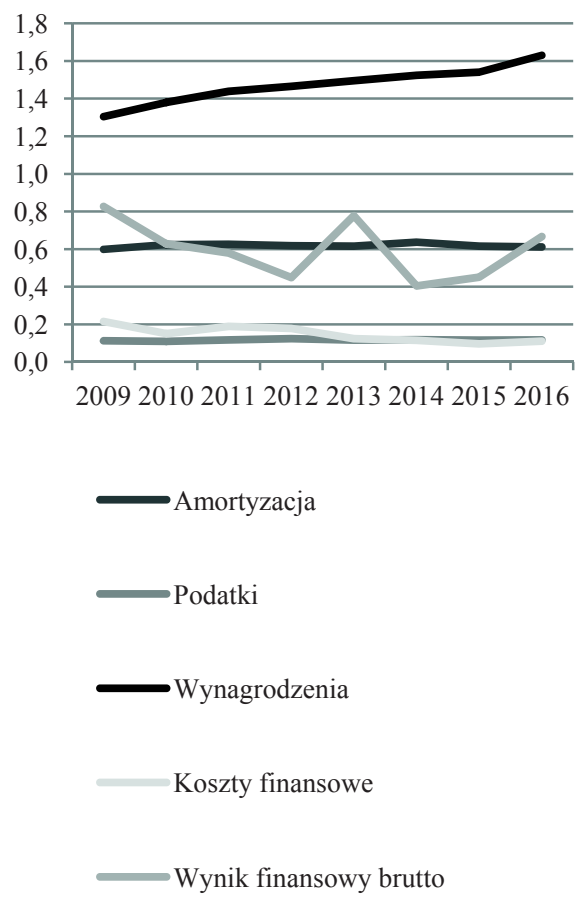

Rys. 5. Składniki wartości dodanej brutto

Fig. 5. Components of gross value added

Źródło: opracowanie własne na podstawie danych GUS.

Rysunek 4 prezentuje jakość pracy w wybranych klasach oraz w całym dziale 10. Jakość pracy jest liczona jako: $\frac{W D B_{t}}{P_{t}}$, gdzie $W D B_{t}$ to wartość dodana brutto w okresie $t$, a $P_{t}$ to liczba zatrudnionych pracowników w okresie $t$. Jednostką na osi Y jest tyś. zł. Można zauważyć, że trend we wszystkich przypadkach jest rosnący. Oznacza to polepszającą się wydajność. Klasa 10.13, czyli produkcja wyrobów z mięsa, włączając wyroby z mięsa drobiowego, jako jedyna miała w całym badanym okresie mniejszą wydajność niż dział 10 . Z kolei w klasie najmniejszej, czyli w wytwarzaniu produktów przemiału zbóż, można zaobserwować wydajność znacznie wyższą niż w dziale 10. Jednocześnie ta sama klasa najszybciej poprawia swoją wydajność, ponieważ współczynnik przy zmiennej $t$ (trendzie) był największy wśród analizowanych przypadków.

\section{Podsumowanie}

Wynagrodzenie, dla każdej z badanych klas, jest głównym składnikiem wartości dodanej brutto. Miało ono udział 51-57\%, 43-52\% i 36-43\% odpowiednio w produkcji 
wyrobów z mięsa, włączając wyroby z mięsa drobiowego, przetwórstwie mleka i wyrób serów oraz $\mathrm{w}$ wytwarzaniu produktów przemiału zbóż. Na podstawie przeprowadzonych badań można stwierdzić, że produkcja wyrobów z mięsa, włączając wyroby z mięsa drobiowego była najszybciej rozwijającą się klasą w całym badanym okresie. Przyczyną był wyższy udział wartości dodanej brutto w wielkości sprzedaży. W tej właśnie klasie, czyli $\mathrm{w}$ produkcji wyrobów z mięsa, włączając wyroby $\mathrm{z}$ mięsa drobiowego zaobserwowano opóźnioną reakcję $\mathrm{w}$ dynamice wartości dodanej brutto na jej procentowy udział w wielkości sprzedaży. W tej klasie w latach 2009-2010 udział WDB był największy w wielkości sprzedaży, a dopiero w roku 2013 osiagnięto znaczny wzrost WDB w stosunku do roku poprzedniego. Z kolei w wytwarzaniu produktów przemiału zbóż (klasa 10.61) opóźnienie jest jednoroczne. Ten związek przyczynowo-skutkowy i opóźnienia z nim związane będzie dalej badany. Analizując wydajność w wytwarzaniu wartości dodanej można stwierdzić, że każda z analizowanych klas polepsza swoją wydajność w badanym okresie, gdzie klasa 10.61 (wytwarzanie produktów przemiału zbóż) rozwija się najszybciej. Analiza wydajności będzie dalej rozwijanym wątkiem, który zostanie poszerzony o kolejne klasy i/lub grupy PKD. Innym rozwijanym zagadnieniem będzie udział wytwarzanej wartości dodanej brutto przez poszczególne klasy, grupy i działy (według klasyfikacji PKD) do całości wytwarzanej wartości dodanej brutto w przemyśle spożywczym.

\section{Literatura}

David, T. (1985). Handbook of Management Accounting, London. Pitman Publishing Limited.

Evraret, S., Riahi Belkaoui, A. (1988). Usefulness of value added Reporting, A review and synthesis of the literature. Managerial Finance 24(11), 1-15.

Główczyk, J. (2000). Uniwersalny słownik ekonomiczny (Universal economic dictionary). Fundacja Innowacja, Warszawa.

Hamulczuk, M. (red.) (2015). Struktury rynku i kierunki ich zmian w łańcuchu marketingowym żywności w Polsce i na świecie (Market structures and directions of their changes in the food marketing chain in Poland and in the world), IERiGŻ-PIB, Warszawa.

Jarzębiowski, S., Klepacki, B. (2013). Łańcuchy dostaw w gospodarce żywnościowej (Supply Chain in Food Industry). ZN SGGW Ekonomika i Organizacja Gospodarki Żywnościowej, 103, 107-117

Lorenc, S. (2016). Metodologie raportowania wartości dodanej dla interesariuszy (Methodologies of Reporting of Value Added to Stakeholders). Organizacja i Zarzadzanie: Kwartalnik Naukowy, 2(34), 127-141.

Morley, M.F. (1979). The Value Added Statement in Britain. The Accounting Review, 54(3), 618-629.

Picur, R.D. (2007). The effects of accounting knowledge on the omission of value added information in wealth measurement and distribution decisions. Review of Accounting and Finance, 6(1), 15-23.

Sielska, A., Kuszewski, T., Pawłowska, A., Bocian, M. (2015). Wpływ polityki rolnej na kształtowanie się wartości dodanej (The impact of agricultural policy on the development of added value), IERiGŻ-PIB, Warszawa.

Sizer, J. (1979). An Insight into Management Accounting, London: Pitman Publishing Limited.

Urban R. (2002). Wartość dodana i marże w przetwórstwie głównych produktów rolnych (Value added and margins in the processing of major agricultural products), IERiGŻ Warszawa.

Do cytowania / For citation:

Krawczak M. (2018). Wartość dodana na wybranych gałęziach polskiego rynku żywnościowego. Problemy Rolnictwa Światowego, 18(3), 187-195; DOI: 10.22630/PRS.2018.18.3.77

Krawczak M. (2018). Value Added on Selected Branches of the Polish Food Market (in Polish). Problems of World Agriculture, 18(3), 187-195; DOI: 10.22630/PRS.2018.18.3.77 